\title{
Bohdan Dziemidok, Filozofia i sztuka życia [The Philosophy and the Art of Life], Lublin: Wydawnictwo UMCS, 2017, pp. 164
}

DOI: http://dx.doi.org/10.12775/RF.2018.033

Is there a prescription for life? It seems that the only reasonable answer for that question is no. No, there is no such thing and, what is more, there cannot be. Even so, people will never cease to search for it. Since the dawn of time, they have tried to answer the fundamental question: how to live one's life well? So far no universal principle has been formulated, despite many attempts.

Quite definitive resolutions to that issue have been proposed by various religious systems, which impose upon people a number of orders and bans. Respecting them is supposed to ensure success in life or, at least, success of a particular enterprise. Some religions are not concerned with worldly life whatsoever and promise a deferred prize awaiting only after death. Instructions provided by religion undoubtedly help many people to live and find the meaning of life; however, one can hardly consider them as truly universal.

On the other hand, secularized societies of late capitalism have turned the human pursuit of happiness into a lucrative business. A huge branch of industry has been established around it offering consumer goods as self-help books, popular psychology publications, and bestsellers promoting fashionable imported life philosophies such as Danish hygge or quasi-Japanese ikigai. The industry also offers a whole variety of services (quasi-therapies, self-development workshops, motivational classes, coaching), more or less serious TV shows, and an awful lot of blogs, vlogs and other content posted on the Internet. Finally, advertisement and marketing also offer their own recipe for satisfactory existence and keep telling us that the more goods we collect, the happier we will be.

As a result, it is easy to forget that the question of how to live well is not meaningless and does not have to provoke only naive answers, as proposed by self-help paperbacks, the false ones as in the case of advertising, or the final and categorical ones, as offered by certain religious 
systems. On the contrary, it remains one of the most important issues of ethics and axiology and is capable of stimulating endless theoretical considerations, which quite often lead to practical advantages. Fortunately, Bohdan Dziemidok reminds us of that in his latest book Filozofia i sztuka życia (The Philosophy and the Art of Life), published by the Maria Curie Skłodowska University Press.

The book consists of eight essays based on a series of lectures given by this well-known and acclaimed philosopher at the Maria CurieSkłodowska University in Lublin. The publication might be seen as the crowning of the philosopher's academic career (in 2016, he celebrated the sixtieth anniversary of his scientific and didactic work) as well as a résumé of his life experiences as a husband, father, friend, colleague as a human being.

Each essay covers a different issue, significant in the context of philosophical thought and relevant from the perspective of human life. The author discusses such vital matters as happiness; analyses the relationship between life attitude and happiness (understood as a psychological well-being and overall satisfaction with life) and inquires the moral aspect of the pursuit of happiness. He also analyses relationships essential to human existence such as love and friendship. Furthermore, the philosopher investigates the role of law, morality, and customs in the regulation of human behaviour, asks about the relationship between contemporary art and morality, argues that old age is an existential problem, and wonders if there are and if there should be any limits to freedom.

The selection of problems discussed in the book is arbitrary; yet, it was not the author's aspiration to consider all the issues of such a complex and varied area as the philosophy of life. Both the contents and the form of the book derive from experiences which the philosopher was going through while writing it.

Bohdan Dziemidok admits that he perceived the work on the publication as a kind of self-therapy after the loss of his wife, a way of coping with the loneliness and sadness. In such moments, questions such as how to live well, how to endure suffering and pain, become more relevant than ever. The philosopher decided to share all the possible answers with readers.

In search of the answers, he refers to both the classics of philosophy and contemporary thinkers. He even embraces achievements of psychology. Then, drawing from the thoughts of others, and his personal experience and observation, the author frames his own conclusions which are presented apprehensively and, at the same time, eloquently. What is more, he also formulates a set of recommendations and practical advice for the readers' sake, which can help them to practice the very difficult art of life. 
Still, in his book, Bohdan Dziemidok does not offer easy tips and banalities like self-help books often do. The author could not be further from formulating final answers either. Instead, he invites the readers to discussion, shares his knowledge, experiences, and thoughts. He explains that, although his advice cannot guarantee a happy life, they might increase the probability that our lives will satisfy us rather than end in complete failure by our own fault.

What are the philosopher's suggestions then? First of all, he promotes realism in every aspect of living and, consequently, rejects excessive pessimism as well as immoderate optimism as attitudes towards life. At the same time, he agrees with Władysław Tatarkiewicz and Dalai Lama XIV, among others, that our happiness and contentment strongly depend on our attitude towards life. What is more, he presents a very moderate vision of the satisfying existence. That creates an evident contrast to ideals and values prevailing in modern Western societies. The philosopher rejects the cult of success, consumerism, and belief in human omnipotence propagated by the so called industry of happiness. He denies the possibility and, more importantly, the necessity of being the best (or "at least" perfect) in every possible area. He believes that these ideals not only guarantee that we will not achieve happiness but are themselves a cause of suffering by imposing unattainable standards. That is why the author argues to restrain one's ambition and to set goals that are achievable.

He also discourages his readers from being envious. He sees envy as a destructive and toxic feeling, nourished by still increasing competition between individuals in the Western world which might ruin one's life. He advises to focus on relationships with other people. He agrees with Leszek Kołakowski that especially friendship is worth cultivating, and it is even seen by him as the most important relationship in human life.

He also believes that we should not expect too much from other people: our life partners as well as strangers. The philosopher seems to say - nobody is perfect, neither are you. However, he does not agree with Freud that people are evil by nature. Still, he believes they are not angels either, so we cannot expect from them to act like ones. As he puts it, people might be bad, but, on the other hand, they are capable of being good and even great sometimes. What is more, it is not uncommon for one man to act foully once or twice while generally being a decent human being. According to the author, we cannot demand heroism or sacrifice from people, but we can and we should demand decency and integrity.

Except having realistic expectations about one's life and being kind towards people and other beings, the philosopher considers a sense of humour and, especially, an ability to laugh at oneself, as a quality that 
helps to live well. But these are only a few tips among many more that the readers can find in the book.

The philosopher admits that his analysis mainly considers these aspects of life which he knows not only from theory, but also from practice. In some parts of the book, the readers might feel as though they were reading the author's testimonies. These are the confessions of a man and a philosopher who confronts his own experiences and struggles with theoretical considerations of other thinkers and verifies them. For example, an essay about the old age, which I find exceptionally interesting, is such a testimony.

The author, with typical self-mockery, describes all sorts of pleasures achievable only to the elderly and completely unknown to young people such as the pleasure of finding keys to one's house or a lost phone. According to the author, finding one's keys before leaving an apartment due to pressing engagement is a very intense pleasure and a kind of satisfaction which youngsters in their forties might only dream to get.

Naturally, not the whole essay is as light and playful as the cited passage. It is also full of bitter considerations about suffering, senility, and irreversible changes affecting body at the old age, about the loss of those who one loved and friends, about the fear of death as well as waiting for it.

Filozofia $i$ sztuka życia puts our everyday bustle into a perspective, the perspective not only of a scientist or thinker, but also of a man with huge and varied experience, who is both a theoretician and practitioner of life. Still, this subjective approach besides the undeniable advantages, has also its drawbacks.

The selection of topics within each essay is mostly determined by the author's personal experience and interests. For example, when discussing the issue of love, he concentrates on the relationship between a man and a woman within a traditional marriage and merely mentions other kinds of relationships such as cohabitation and polyamoria. Furthermore, not at all does he include the issue of love and erotic relationship between partners of the same sex. In paragraphs considering gender issues, the philosopher also presents a fairly traditional stance. He highlights differences between men and women and draws a rather rigid division between the sexes in terms of typical traits or "normal" behaviours. At the same time, he omits the issue of different socialization of sexes.

On the other hand, the author calls himself an "unorganized feminist" and does show some feminist sensitivity, for example, when stating that the division of roles and the type of relationship between partners are strongly influenced by their personalities or when discussing still prevailing double moral standards for women and men. Nonethe- 
less, as a more organized feminist, I am obliged to point out these inconsistencies.

In the book Filozofia $i$ sztuka życia Bohdan Dziemidok makes an attempt, and undoubtedly a successful one, to grasp human life and put it into the philosophical perspective. By doing so, he reveals how tightly philosophical theory is linked to life practice. What is more, due to incredible sincerity and an exceptional sense of humour, he creates a strong bond with his readers.

As a result, the author has created a philosophical guide which introduces the readers to selected existential problems. At the same time, it is a unique self-help book which might help the readers to face these problems, as they are given an opportunity to look at them from a philosophical distance, avoiding excessive pessimism as well as unreasonable optimism. Although the book does not provide a ready recipe for happiness like self-help bestsellers do, it offers experience and knowledge. It also makes one think and, as far as I am concerned, that is a good starting point if one wants not only to live well, but also to live wisely.

Anna Małyszko

SWPS University of Social Sciences and Humanities,

Warsaw, Poland

ORCID: 0000-0003-4550-2197

e-mail: anna.m.malyszko@gmail.com 